\title{
Higaonon Oral Literature: A Cultural Heritage
}

\author{
Rennie Cajetas-Saranza \\ Philippine Normal University, Mindanao, Philippines
}

\begin{abstract}
Ethnic oral literature preservation contributes to the development of a national culture. This study aimed to document the indigenous oral literary genres of an ethno linguistic group in Agusandel Sur, the Higaonons; and analyze these in terms of richness in human values, symbols, imagery, point of view, and characterization. The study sought to determine further the indigenous knowledge in the transmission and preservation of these oral literary pieces as cultural heritage. The researcher used purposeful sampling and in-depth interviews, categorizing oral literature in terms of prose and analyzing them using the formalistic approach. Results revealed that the Higaonons have rich oral literature categorized by prose as short stories, essays, and legends narrated by the key informants in the omniscient point of view. The common human values reflected in their literature include patience, courage, godliness, and industry. The wearing of beads and Higaonon costume symbolizes pride and identity of the tribe. The literature includes vivid images that appeal to the senses of the readers. They are transmitted and preserved through storytelling only by the datus of high rank of whom knowledge of all tribal lore is a requisite may reveal the story; and in their yearly Kaamulan Festival.
\end{abstract}

Keywords: literature, Higaonon oral literature, indigenous knowledge, formalistic approach, Agusan del Sur, Philippines

\section{Introduction}

Philippines, basically an archipelago, has a variety of ethnic groups inhabiting its land. The languages spoken by these ethnic groups are Austronesian in origin. The culture of the Philippines has been influenced by many different cultures of the world. It has a large number of tribes that in spite of enduring years of colonization, the descendants of the original inhabitants have been able to preserve the culture particularly the oral tradition.

Philippine oral tradition continues to exist through literature genres despite vast influence of Spanish, Japanese, and American colonization (Macasantos \& Macasantos, 2012). These oral literature serve as sources of social, economic, environmental, and philosophical knowledge. Hampate (1981) considered that "Oral literature as a reflection of the great school of life, because all aspects of it are covered and affected by it." The National Commission on Culture and the Arts (NCCA) (2011) further recognized oral literature as an essential tool for non-literate people to acquire a wide range of knowledge of various aspects of human beings which no scientific treatise, textbook, or any journal can provide.

However, United Nations Educational, Scientific, and Cultural Organization (UNESCO) (2012) reported the danger of extinction on oral literature mainly because of their intangible character. Being intangible cultural expressions, local communities themselves often do not see the significance of preserving their cultural heritage. The case of the indigenous people in Canada and Indonesia (Battiste, 2002, as cited in Czermak, Delanghe, \& 
Weng, 2003), as well as the Tausugs and Maranaos in the Philippines (NCCA, 2012) consider their cultural heritage as backward and a hindrance to their ability to access "modern society" and economic wealth. NCCA (2012) further noted that at present, Filipino Muslim cultural communities are seemingly preoccupied with mundane considerations, such as politics and economics.

The case of the Higaonon tribe, the Northern and Central regions of Mindanao, particularly in the provinces of Misamis Oriental, Bukidnon, Agusandel Sur, Agusan del Norte, and Lanao del Norte, are their habitations. Among all the ethnic groups of the area, Higaonons are the least known. They are described as the "people of the living mountains" and "people of the wilderness." Their name is derived from "higa" means "to live or reside," "gaon" means "mountain or highland," and "onon" means "people." The culture of the Higaonon tribe can be best described as one of peace, for solving the internal conflicts of other ethnic groups. They practice an ancient ritual called Tampudashu Balagun, which means "treaty of the green vine branch;" literally, means cutting the vine and symbolically, cutting disputes between ethnic groups. The Bunkatol Ha Bulawan Daw Nang Ka Tasa Ha Lana ("Treasured unity of love and peace") is a code of conduct they faithfully follow, a sacred bond that unites their community (Ethnologue, 2015).

In Agusandel Sur Philippines, the Higaonons settled in the mountains of Salug, Esperanza, Homogaway, and Bayugan. They practice kaingin farming (rice, corn, camote, taro, coffee, and bananas) and are also hunters and gatherers. The tribe is very rich in its oral traditions. However, there is a danger of extinction because inquiries at the provincial government as well as the Department of Education neither revealed meager records of the culture of this cultural communities of the province, nor were there any of oral traditions. Considering that the ranks of the tribal elders are rapidly dwindling, the researchers felt that a written account of the Higaonon tribe's oral literature be documented before it is too late. Higaonon oral literature may never get into print because of taboos that forbid their retelling. Only the datus of high rank of whom knowledge of all tribal lore is a requisite may reveal the story. Even then a ritual involving the butchering of a pig is mandatory to appease the spirits whose wrath may descend on the narrator for revealing the sacred lore. There is a danger of losing the Higaonon oral literature soon if this will not be given attention for preservation.

Ball (2011) stressed that leading scholars who recognized the embodiment of oral literature in local languages promote a worldwide movement to recover, develop, and sustain indigenous languages. They predicted that of the approximately 6,000 languages presently spoken in the world, only half to one-tenth will be spoken by the end of the 21st century (United Nations Educational, Scientific, and Cultural Organization [UNSECO], 2008). This may contribute to the vanishing of heritage literature.

It is in this light that the researcher resolved to document the indigenous oral literary genres of an ethno-linguistic group in Agusandel Sur, the Higaonons. Specifically, this study aimed to analyze these in terms of richness in human values, symbols, imagery, point of view, and characterization. The study sought to further determine the indigenous knowledge in the transmission and preservation of these oral literary pieces as cultural heritage. At the same time, the output of this research can be used as basis in crafting culturally appropriate instructional materials integrated in the community's mother tongue.

\section{Framework}

This study is anchored on the theory of Manuel (1969) that oral literature can be a valuable material for historical interpretation. The body of native literature can also be the course of information of the life ways of proliferating societies, which could form part of the national literature. There is also pleasure derived from 
knowing such thing, but this is only possible after a sufficient body of myths, folktales, or legends have been collected from the area sought to be covered. Given the non-survival of written records about national history, we may not have the firmness of foundation to our oral traditions. It is this rarely unknown literature that holds much promise understanding our past and linking our culture to our past.

Oral traditions can as much be the foundation of national literature as creative writings are, and the literary historian cannot just ignore them. They become basic in cultures ravaged by nature, time, and the circumstance of history. If these have not been availed to the fullest by writers of literary histories in his country, it is because of our own unawareness of the value and importance of such traditions or our indolence to go to the field (Manuel, 1969).

\section{Methodology}

\section{Research Design}

The study employed ethnographic research design. Ethnographic techniques included in this study are direct, firsthand observation of daily behavior, including participant observation; conversation with varying degrees of formality, from the daily chitchat that helps maintain rapport; interview with the Higaonons of varying ages; and focus group discussions. The researcher got to the informants and usually took interest in the totality of their lives (Kottak, 1991).

\section{Participants}

It used the purposive sampling of seven informants and 10 participants with age ranging from 60 to 83 who were datus and their wives and native speakers of the Higaonon language in Esperanza Agusandel Sur. There were 20 literary pieces in prose and poetry narrated by the key informants. Out of 20, only five literary pieces categorized as prose were chosen and considered by the researcher for analysis. Experts in both Higaonon and English languages transcribed and translated the literary pieces.

\section{Procedure}

Data collection for this qualitative study utilized multiple sources. The resulting information from these sources created a triangulation or convergence of sources (Creswell, 1998). Patton (1987) explained that a triangulation is the comparison of observational data with interview data; checking the consistency of what people say; and comparing the perspectives of people with a different point of view. It means validating information obtained through interviews by checking documents and other written evidence that can corroborate what interview respondents report. In this study, the triangulation of data was accomplished in multiple sources including informant interviews, focused group discussion of the participants, observations, and field notes. The convergence of these sources provided a scaffold for data analysis.

Analysis of data was done using the formalistic approach. A formalistic approach to literature once called New Criticism, involves a close reading of the text. Formalistic critics believe that all information essential to the interpretation of a work must be found within the work itself. Formalistic critics spend much time analyzing irony, paradox, imagery, and metaphor. They are also interested in the work's setting, characters, symbols, and point of view (Hamilton, 1999). In this study, it involved an analysis of the literary pieces in terms of richness in human values, symbols, imagery, point of view, and characterization. It also discussed the indigenous ways of transmitting the literary genres from one generation to the next, and how to preserve the oral literature as cultural heritage of the Higaonons. 


\section{Results and Discussion}

\section{Analysis of Selected Higaonon Literature in Terms of Human Values, Symbols, Imagery, Point of View, and Characterization}

The laws at Mt. Sinakungan (Butos ta Sinakungan). Higaonon ancestors' laws entail values that human beings need to possess. These include justice, fair judgment, trustworthiness, honesty, obedience to superiors, efficiency in doing the job, loyalty to the laws, and harmony among people. Datu Indulum was said to have formulated the "Butos Ta Sinakungan" on the historic Mt. Sinakungan. The Butos Ta Sinakungan stipulated the following: Respect should be accorded to the datu who is the tribe's protector and law-giver; killing is against the law unless sanctioned by the tribal council; trespassing on another's property is against the law; marriage to a son or a daughter, a brother or a sister, a close relative, a father-in-law or a mother-in-law and another relatives is prohibited; stealing or gambling is punishable by law; rape and/or elopement are grave offenses; breaking of the laws should be given speedy counteraction; and transgression of the laws mentioned above is punishable with death. Justice was dispensed equally whether the accused was a slave (sakop), or a member of the ruling class. An offender was entitled to a defender, usually a datu, one commanded personal respect, and therefore, wielded real authority. In the close of the deliberation, the defender may have to act as mediator and guarantor of the individual he represented. If the sentence was the payment of the compensation, the defender had to assume the responsibility should the offender be unable to raise the required fine.

The symbols that could be found from this essay include the gift of bahandi (money) to the girl's parents, mangad (gift of goods and money to the bride's kin), cooked rice shaped into an egg, marriage contract, and food and chicken blood to sanctify their vow. The marriage contract symbolizes love and commitment of the couple who decided to engage in a deeper relationship. It is the bond of their vows to be one in the flesh as long as they live. Money symbolizes happiness, for, without it, man is in sadness. They used money in all undertakings and endeavors; therefore, it is very vital to a person. Food symbolizes life; without it, man will not survive. The river played a significant role in the life of the tribe in the early days as it does today. It was their source of food, water for drinking or washing, and a place for bathing and washing clothes.

The essay includes images that directly appeal to the senses of the reader. These include peace and harmony, conflicts being settled (feelings), money, a paper of agreement, and food for celebration (taste). The Higaonons are law-abiding and peace-loving people. They maintained a harmonious relationship with each other. Having the conflicts settled, the Higaonons usually prepared food as a celebration.

The author used the omniscient point of view narrating the details of the essay. He knows each member of the judicial system since he is a datu. He has sufficient knowledge of the functions and responsibilities of the tribal leaders and members. He knows their power as well as their limitations.

To characterize the people involved in the judicial system of the ancient Higaonons, the ininay as supreme datu has the highest power, authority, and will. He is highly respected and honored among all people. He enforced controls as a supreme datu, assisted by other datus who, forming a council, acted within the tribe or for the tribe in dealing with outsiders. These datus governed more by persuasion than force over the sakop, that is, the members of the community, and the slaves. The alimaong provided protection to the leaders and communities they govern. The main duty of the alimaong was to protect the supreme datu.

The legend of the carpenter (Nanangun ko tighinang ko balay). The legend entails human values such as obedience, endurance, and patience. David, the main character, showed these when he obeyed his friend 
Diwata. Because of his virtue, he was given the strength and wisdom to design and build houses. These qualities are requirements for a man who desires to help his community. There is a need to endure and remain patient to be able to achieve one's goal in life.

The symbol that the author find from this legend is the house that speaks of the Higaonons' sense of territory, ownership, and family. Higaonons are known to be nomadic, but when they started building their homes near the river, they learned to stay in one place and call it their own. They kept their family intact where love and abundance reign among the members. Higaonon dwellings were one-room affairs built from materials abundant in the environment like round wood, buri, rattan, and cogon leaves. The house, constructed along simple lines, looked like unfinished frameworks devoid of walls. The extended members of the family which comprised the household, distributed stoves, and stairs around the single room. Each family had their own stove on which to cook their meals, and stairs with which to gain access to their specific space in the house.

The legend includes vivid images like the huge spider as big as a saucer that the main character David saw in the woods. Another image is the round, shining stone that David took from the spider's stomach and which he buried in his muscles that give him the ability to design and make houses. All of these appeal to the sense of sight to the readers.

The point of view used in this story is a limited third person as the key informant knows the names of the characters. The key informant is so knowledgeable on this legend since he has been a carpenter for 70 years. This legend was passed on to him by his grandparents who were also carpenters.

The main character in this legend is David. David's curiosity made him open the stomach of the spider from which he found the stone that gives him the wisdom of designing and building houses as indicated in the story.

Higaonon marriage and family (Pug-asawa daw taglaasa ko mga Higaonon). Among the early Higaonons, the onset of marriage was marked with certain social signals. The father chose his son's bride-to-be, and arranged the betrothal between parents. The groom or his kin performed the bride service before marriage and gave the bride price to the bride's kin. The essay speaks of desirable qualities that are requirements and criteria set by the bride's father in choosing the husband of his daughter. The human values that the author found from this essay include godliness, industriousness, and patience. These qualities that are pleasing to the eyes of the society make a man worthy to become a husband and a woman to become a wife. Being industrious is seen when the suitor will render the panakin or bride service required of him for months or a year or over a year as the case may be. He must be industrious, responsible, and God-fearing type of person. God-fearing is a leading human value. If a husband possesses it in his heart, other values will just follow. If he is religious, then it is natural for him to be hardworking, industrious, and responsible, because he cannot just afford to see his family suffer from hunger. It contains human values such as patience and perseverance in the process of weaving by the woman.

The symbol in this essay is the mangad, the gift of goods, and money to the bride's kin by the groom or his kin. Every member of the girl's family — the girl's mother, her grandparents, and her nurse — all who had a direct hand in her upbringing had the right to demand a share of the mangad. Another symbol is the Higaonon costume used by the bride, groom, datus and kin of the bride, and groom during the wedding symbolizes pride and living treasure of the Higaonons.

The essay appeals to the sense of seeing and feeling. On the day of the wedding, the datus performed the ceremonial pangagda preparatory to entering the bride's home where the wedding ceremony was to take place. Arranging themselves into two lines before the house, they marched solemnly into a bride's dwelling accompanied by the beating of agongs (a large metal disc that makes a ringing sound when struck with a 
padded hammer). The marriage ceremony itself is the sense of seeing. Included are the rite of the pamalas, the panawag-tawag, and blessing of the couple. In the pamalas rite, the palms of the bride and the bridegroom were smeared with chicken blood to sanctify their vows. The panawagtawag consisted of oath-taking by the couple and the pangapongon, the prayers intoned by the datus invoking the ancestral spirits' blessing on the couple. It also includes the sense of feelings as indicated in the focus group discussion, like loving the partner, being religious to God, and remaining faithful to the partner. Love must be existing between husband and wife to establish a harmonious relationship within the family. The key informant used the omniscient point of view as he has sufficient knowledge on how Higaonons chose a partner for marriage before because he experienced the same custom as passed on to him by his parents.

The main characters are the man and the woman. The woman is described to be godly, industrious, hardworking, faithful, religious, and skilled in weaving. In addition to working in the kaingin (clearing land by slashing and burning under brush and trees and plowing the ashes under for fertilizer), the women were part-time craftsmen. They wove baskets and mats for home use as well as for trading. They had a simple form of weaving, done by hand, for making bags and mats. Kamuyot bags fashioned from rattan were made on native handlooms. The materials used for basket making were nito, rattan, or bamboo while they wove the mats from tikog and baloy leaves. Finished handicrafts were bartered for goods brought by traders who came by way of the AgusanRiver. The man, on the other hand, must be industrious, hardworking, faithful, and religious to his duty as the bread-winner of the family. The parents of the woman also chose the kind of man to be the husband of their daughter to ensure that the man can feed their daughter and the children to be. The parents are the minor characterswho are choosy due to their concern of their son's/daughter's future.

Higaonon beliefs and practices (Mga panuos daw mga hinang ku Higaonon). Strong faith and gratitude are the values evident in this essay. The Higaonons believed in supernatural beings that dwelt in mountains, forests, trees, or simply existed in some portion of the universe. They also believed in the existence of beneficent spirits like those of their dead datus as well as in malevolent ones, and in the creator of all things - the God Magbabaya. Rituals and ceremonies have remained a part of the Higaonon way of life until the present. The tribal community held a Kaamulan Festival any time during the year either to give thanks for a good harvest, to celebrate a victory, a wedding, a baptism, or a family reunion.

The symbols found in this essay are the white pig, the community's offering and a sacrifice for continued beneficence in the forthcoming planting seasons. The traditional butchering of fattened pigs at the foot of the stairs of the tribal chieftain's dwelling marked the formal opening of the celebration.

The essay has a lot of images that appeal to the readers' senses. The white pig, the bathing in the flowing blood symbolizing cleanliness from guilt, the cooing of the limokon (pigeon) symbolizing assurance of a good harvest,appeal to the readers' sense of hearing.

The essay uses the omniscient point of view in unfolding the details of the events. The informant knows the thoughts and actions of each character. He manipulates the events by delving into the characters' minds.

The main characters in the essay are the datus who performed the ritual in the Kaamulan festival. The datus gathered around offering prayers to Ibabasok, the good spirit of the harvest. They also offered prayers of thanksto the spirits of the departed datus.

Higaonon verbal arts (Higaonon ha mga limbay daw dasang). The value of aesthetics and creativity are evident in this essay. Like most people, Higaonons experience the need to express their feelings and ideas through an artistic medium. They revealed these feelings and experiences in their songs, prayers, verbal jousts, 
and folklore that mirrored the beliefs and concerns of their society.

The dasang, a high form of literary speech, is delivered accompanied by increasing frenzied movements of the performers (speech choir in theater). It symbolizes Higaonons' love and appreciation for verbal arts and their literature which is performed only in gatherings with special significance. The performance of the dasang which is a combination of chants and dances; and the Sangon/balod, a speech form similar to the balagtasan, is a verbal joust between two individuals usually a male and a female. The pangapogon, a prayer calling on spirits residing in nature and spirits of the ancestors and gods, appeal most to the sense of hearing. This prayer is chanted by a datu in special gatherings only.

The key informant, who is a datu, used the omniscient point of view in this essay. He is knowledgeable for he once performed the Sangon/balod.

\section{On the Preservation and Transmission of Higaonon Oral Literature}

The Higaonon informants identified the Kaamulan Festival as the only means of preserving their culture. The Kaamulan Festival is a kind of celebration anytime during the year which aims to give thanks for a good harvest, to celebrate a victory, a wedding, a baptism, or a family reunion. The members of the tribe and those of the neighboring local groups come together for the celebration. They showed their customs and traditions, such as folk songs, oratory, poems, dances, and customs that are almost forgotten today. It also involves an authentic showing-off of their weapons, clothing, dressing, and weaving. It also shows the agricultural aspects of farming (planting and harvesting) which is accompanied by the beating of percussive musical instruments. "We believed that harvest becomes abundant if planting is accompanied with the singing and beating of gongs and other percussive instruments," stressed by an informant who is a datu.

These are the practices of the Higaonons as to the preservation of their literature. They wished that their stories be written in books so that these can be remembered and learned by the next generations. The emergence of diverse culture in Esperanza, Agusandel Sur is a threat to the banishing Higaonon cultural heritage. It is the fear of the old Higaonons that sometime in the future their descendants might no longer cherish their culture and might lose their identity.

\section{Conclusion}

Oral literatures are found significant in the society's socio-cultural experience over the past and present decades across cultures. Nigerian oral poems, for example, are rich in cross-cultural animal symbolisms that stimulate and sustain national consciousness and national unity (Eyoh, 2011). Some critics also say that they do not only serve to entertain the society, but are also an instrument of cultural education, because as they embody history, cultural values philosophy, and beliefs of the people, we learn a lot from them.

In the same way, the Higaonon literatures are all handed down through oral narration by their forefathers. They have varied literary pieces categorized by prose according to the genre as short stories, legends, and essays. The essay on the origin of their ancestors' laws stressed that Justice was dispensed equally whether the accused was a slave or a member of the ruling class. The Legend of the Carpenter talks about the fantasy involving the presence of the Diwata and the spider which entails wisdom in designing and building a house. The essays entail criteria set by the bride's father in choosing the life-time partner of his daughter in marriage; the beliefs and practices as shown in festivals; and expression of their feelings and ideas through an artistic medium which is evident of their love for verbal arts. 
The oral literature of the Higaonons contains human values, imagery, symbols, point of view, and characterization. The most common human values extracted from the essays include patience, godliness, and industry. Patience is exercised in the rearing of children, in farming and in fishing. Higaonons are peace-loving people. They abhor disunity in the community for they want harmony to prevail among them. One most common symbol from the literary pieces is the wearing of the Higaonon costume which stands for pride and identity of their tribe. The legend and essays include vivid images that appeal to the senses of the readers which the informants narrated in the omniscient point of view. These oral traditions play an important role in defining good citizenship and maintaining a harmonious social fabric, because even the subtleties of social structure and interaction are encoded in their tradition (Chandra \& Sentinaro, 2009).

However, Higaonon myths, legends, and tales may never get into print because of taboos that forbid their retelling. Only the datus of high rank of whom knowledge of all tribal lore is a requisite may reveal the story. Even then a ritual involving the butchering of a pig is mandatory to appease the spirits whose wrath may descend on the narrator for revealing the sacred lore. There is a danger of losing the Higaonon oral literature soon if this will not be given attention for preservation.

In addition to the weakening importance of preserving oral traditions, linguistic scholars who recognized that oral literatures are expressed, articulated, and perpetuated through the use of local language identified the disappearance of linguistic diversity through the use of dominant language in educational institutions as another factor for the vanishing of oral literatures (Magga, Nicolaisen, Skutnabb-Kangas, Trask, \& Dunbar, 2012). What are supposed to be a tool for transmission of such cultural heritage through formal and informal education are suppressed by enforced subtractive education where teaching method subtracts from the child's linguistic repertoire, instead of adding into it (Magga et al., 2012). The same author also noted that parents' right to intergenerational transmission of values, language, and oral traditions are hampered for they are encouraged by the dominant-language norm in support for their children's learning.

In order to overcome this challenge, developed as well as developing countries responded to the global call for the valorization of the home language and culture that is resulting from the espousal of a mother tongue-based education (Ball, 2011). With this, cultural determinism is revived, where, as in the case of Nigeria, it is an attempt to return to Nigerian identify and African roots (Chandra \& Sentinaro, 2009). This also means the preservation of the oral heritage as pushed by the World Oral Literature Project (Appel, 2010). Among the actions taken by UNSECO was the recently formulated Convention on the Safeguarding of the Intangible Cultural Heritage, among which are oral literatures and indigenous language, especially among minority groups whose cultural heritage are at great risk (Czermak et al., 2003).

In the implementation of the K-12 curriculum vis-à-vis Mother Tongue-Based Multilingual Education (MTB-MLE), the results of this study should primarily be used as reading materials. The compiled literature can be used by the teachers as instructional materials in the preparation of lessons and exercises for the Higaonon learners of English without losing their cultural identity.

Cultural transmission is also assured with mother tongue-based system of education. The Council for Research on Values and Philosophy (2012) cited an example that a type of tradition which remained firmly engraved in people's memories was used to associate with it another tradition more easily forgotten. Hornberger (1994, as cited in Benson, 2004) noted that increasing numbers of mother tongue readers and writers will inevitably lead to fuller social participation, that which includes revitalization and perpetuation of their own cultural heritage, not only their language but also their oral literatures. 
This study can further provide a basis for the study of other minority languages and geographic affinities of languages. The present study focuses only on prose. Future researchers can also consider the analysis of other genres like fables, lyric poetry, proverbs, riddles, and epics.

\section{References}

Appel, G. (2010). The Sabah oral literature project. In World oral literature project: Voices of vanishing worlds. Cambridge, U.K.: World Oral Literature Project.

Ball, J. (2011). Enhancing learning of children from diverse language backgrounds: Mother tongue-based bilingual or multilingual education in early years (Analytical review by UNESCO education sector). Paris: UNESCO.

Battiste, M. (2002). Indigenous knowledge and pedagogy in first nations education a literature review with recommendations. Retrieved from http://www.afn.ca/uploads/files/education/24._2002_oct_marie_battiste_indigenousknowledgeandpedagogy _lit_review_for_min_working_group.pdf

Benson, C. (2004). The importance of mother tongue-based schooling for quality education. Paper commissioned for The "EFA Global Monitoring Report 2005, the Quality Imperative, "UNESCO.

Chandra, N., \& Sentinaro, I. (2009). Culture as reflected in Achebe's works and Ao Naga literature. Journal of Literature, Culture and Media Studies, 1(2), 188-199.

Conde, C. (2005). A study of usipun and the Bikol narrative tradition (Unpublished doctoral dissertation, College of Arts and Letters, University of the Philippines).

Council for Research on Values and Philosophy. (2012). The role of oral traditions in Oromo environmental ethics and related issues. Retrieved from http://www.crvp.org/book/Series02/II-13//chapter-11.htm

Creswell, J. W. (1998). Qualitative inquiry and research design: Choosing among five traditions. Thousand Oaks, C.A.: Sage Publications, Inc..

Czermak, K., Delanghe, P., \& Weng, W. (2003). Preserving intangible cultural heritage in indonesia: A pilot project on oral tradition and language preservation. Retrieved from www-01.sil.org/asia/ldc/parallel_papers/unesco_jakarta.pdf

Ethnologue. (2015). Higaonon. Retrieved October 14, 2015, from www.ethnologue.com

Eyoh, L. (2011). Indigenous oral poetry in Nigeria as a tool for national unity. Journal of Communication, 2(2), 83-91.

Hamilton, E. (1999). Formalism and new criticism. Durham, N.C.: Duke University Press.

Hampate, A. (1981). The living tradition: General history of Africa. Ithaca, N.Y.: Cornell University, Africana Studies And Research Center.

Kottak, C. P. (1991). Cultural anthropology. New York, N.Y.: McGraw-Hills Inc..

Macasantos, C., \& Macasantos, F. (2012). Philippine literature in the Spanish colonial period. Retrieved from http://www.ncca.gov.ph/about-culture-and-arts/e-books/e-book.php?id=3\&t=1

Magga, O., Nicolaisen, I., Skutnabb-Kangas, T., Trask, M., \& Dunbar, R. (2012). Indigenous children's education and indigenous language. Expert paper written for The United Nations Permanent Forum on Indigenous Issues, United Kingdom.

Manuel, E. A. (1969). Agya, the Illianon epic of Mindanao. Manila: UST Press.

National Commission for Culture and the Arts. (2011). Laws-katutubo/indigenous peoples of the Philippines. Retrieved from katutubo.lorenlegarda.com.ph/category/laws

National Commission for Culture and the Arts. (2012). Intangible cultural heritage of the Philippines. Retrieved from https://en.wikipedia.org/wiki/Intangible_Cultural_Heritage_of_the_Philippines

Patton, M. Q. (1987). How to use qualitative methods in evaluation (No. 4). Retrieved February 3, 2014, from http://goo.gl/W5k2a5

United Nations Educational, Scientific, and Cultural Organization (UNESCO). (2008). International year of languages. Retrieved from http://www.un.org/en/events/iyl/ 